See discussions, stats, and author profiles for this publication at: https://www.researchgate.net/publication/337842514

\title{
Urban austerity and activism: direct action against neoliberal housing policies
}

Article in Housing Studies · December 2019

DOI: 10.1080/02673037.2019.1697800

1 author:

Valesca Lima

Maynooth University

26 PUBLICATIONS 43 CITATIONS

SEE PROFILE

Some of the authors of this publication are also working on these related projects:

Project Book - Participatory Citizenship and Crisis in Contemporary Brazil View project

Governing cities in the era of sharing economies View project 


\section{Urban austerity and activism: direct action against neoliberal housing policies}

\section{Valesca Lima}

To cite this article: Valesca Lima (2019): Urban austerity and activism: direct action against neoliberal housing policies, Housing Studies, DOI: 10.1080/02673037.2019.1697800

To link to this article: https://doi.org/10.1080/02673037.2019.1697800 



\title{
Urban austerity and activism: direct action against neoliberal housing policies
}

\author{
Valesca Lima
}

School of Sociology/Institute of Social Sciences, Maynooth University, Maynooth, Ireland

\begin{abstract}
The struggle for affordable housing reflects the widespread structural tensions that exist between property markets and the provision of housing. Recent years have seen frequent protests that have highlighted problems in the Irish housing sector, along with the emergence of various housing movements, especially in Dublin, where the lack of affordable housing is severe. This paper argues that these campaigns have contributed to the increased public debate on commodified housing models, signalling a strong demand for a coherent and inclusive national housing policy in Ireland. In particular, I examine the activities of the Home Sweet Home movement $(\mathrm{HSH})$, a collective organization of housing activists that occupied the Apollo House building in Dublin's inner city in 2016-2017. This movement challenged private housing market solutions and the central role played by financialisation in economic and social life. Whilst considering that Ireland is suffering a housing crisis which cannot be easily solved, this paper combines a critical analysis of housing movements that resist neoliberal housing models, the $\mathrm{HSH}$ action in this context, and the challenges involved in changing the government's approach to housing.
\end{abstract}

\section{Introduction}

The impact of different waves of neoliberalism in cities has consequences for contemporary activism. In turn, social movements develop strategies as a response to different waves of neoliberal urban policies. Current social protests and claims by urban movements are a reflection of neoliberal policy designs and enclosures (Mayer, 2013). The economic recession that hit European governments in 2008/2009 had major consequences for public welfare. The crisis that ensued accelerated the process of commodification and financialization of housing, and many cities are experiencing increasing levels of housing shortage and homelessness.

The recent wave of social mobilisation for the right to housing signals a call for fundamental changes in housing policies, including support for major publicfunded housing construction and the end of evictions into homelessness. Housing activists inlreland and beyond have brought the housing crisis to public prominence (Watt and Minton, 2016). In Ireland, the emergence of social protest 
has been a response to the challenges of economic recession and neoliberal austerity policies. This increase in collective action can be seen, for example, in the water charges protests, where people in Ireland broke the cycle of blind obedience to state austerity policies by refusing to pay a newly created water tax (Power et al., 2016). This also evident in the recent wave of housing activism that has mobilised thousands of Irish people who are struggling to afford housing or struggling to keep their current homes.

The aggravation of the housing crisis has also led to a perceived intensified level of protest and contestation against urban austerity policies, indicating a shift from resilience towards more direct forms of resistance within contemporary urban political struggle (Gaynor, 2018; Mallon, 2017). The international debates on the post-economic crisis have only started to explore the dynamics of the housing crisis and the associated political responses in Europe. More recent work has investigated the response of social movements to the crisis and how actionprotests for the right to housing set up a resistance to government marketoriented solutions to market problems (Brickell et al. 2017; Feliciantonio, 2017; Gaynor, 2018; Hearne et al., 2018; Lancione, 2019; Naughton, 2015; O'Callaghan, 2018). This paper makes a specific contribution to the emerging scholarship on housing activism, homelessness, and resistance, as the empirical and theoretical basis of the everyday politics of housing movements are examined in terms of strategies for policy change. Those changes, I claim, have practical implications from the point of view of highlighting the increasing levels of family homelessness in Ireland.

Due to the financialisation of housing in today's market, housing risks are increasingly becoming financial risks (Aalbers and Haila, 2018). Irish housing was subjected to prolonged market reforms from the mid-90s onwards, which fuelled a property bubble caused by deregulation in the banking sector and a government commitment to expanding home ownership (Waldron and Redmond, 2014). However, since 2007, the situation has reversed. Ireland suffered one of the strongest and longest housing market and economic busts of the global financial crisis (Norris and Byrne, 2017; O'Callaghan et al., 2015). Such a housing crisis is felt nationwide (street homelessness, housing shortage, soaring rents and housing insecurity), although it has particularly pernicious effects in Dublin, where asking rents have been increasing 12\%, year-onyear, on average (DAFT Report, 2018).

Homelessness is on the rise. 9,968 people were living in homeless accommodation in November 2018 (of whom 3,811 are children), an increase of $42 \%$ on the number of people when compared to the same period in November 2016 (DHPLG, 2019). These numbers do not include those sleeping rough, people 
couch surfing, tenants renting in the private rental sector in receipt of social housing supports - such the Housing Assistance Payment (HAP) and the Rental Accommodation Scheme (RAS) - and those in Direct Provision Centres ${ }^{1}$ (Peter McVerry Trust, 2018). In December 2018, a total of 71,858 households were registered for social housing in Ireland (Housing Agency, 2018). Rent prices have reached a level where rents rose nationally by $10.4 \%$ in a year-on-year change in the average asking rent (RTB, 2018), forcing people into spending an unsustainable $50-60 \%$ of their incomes on rent alone, on often substandard private accommodation (Social Justice Ireland, 2019).

The study offers empirical insights into the high-profile building occupation organised by the Home Sweet Home (HSH) group. Over the Christmas period of 2016, HSH activists and homeless people occupied Apollo House, a disused building owned by NAMA (National Asset Management Agency). Despite leaving the building after an eventful, month-long occupation, the group was able to draw attention to Ireland's unsustainable housing and homeless crisis and the poor quality of available emergency accommodation in the country. They challenged the state by highlighting the failures of neoliberal commodified housing models, while demanding (and offering) alternative ways for the fair use of urban space. I argue that the contentious political landscape in Ireland is changing through responses shaped by increasingly financialised property market dynamics. I explore this emerging cycle of protest and change in the Irish repertoires of contention by using a social movement theory, such as contentious politics, to think through the ways austerity and neoliberal urban governance drive alternative social projects that confront, criticize and attempt to respond to crises with new repertoires of direct action.

This paper is organized as follows: the next section outlines the theoretical framework used in the article, which draws on social movement literature in order to shed light on the neoliberal policies that are implemented through austerity thereby influencing the growth of, and changes in, social movements. This is then followed by a presentation of the paper's methodology. In section four, I examine the recent waves of mobilisation for the right to housing in Ireland. The background of the building occupation, and the events that unfolded, form the basis of section five. In section six, I examine HSH strategies and the outcomes of social protests. This includes a consideration of social movements and their relationship with neoliberalism. Finally, in section seven, I conclude with reflections on the implications of the HSH occupation for contemporary urban social movements that are grappling with the financialization of the urban space and transformations in the Irish political landscape. 
2. Anti-neoliberalism resistance, social movements and housing policies: an analytical framework

The housing bubble that plunged countries on the European periphery into a severe financial and political crisis renewed interest in studies on how the traditions of social movements interact with external macro historical conditions (Della Porta, 2017; Fominaya, 2015; Yates, 2015 ). Neoliberalism and austerity governance models have been confronted by popular opposition (Cox and Nilsen, 2014), ranging from the global Occupy Movement to the Indignados in Spain and the Right2Water protests in Ireland. The contextual characteristics of the development of anti-austerity protests are connected to the financial crisis and austerity policies that follow. Those movements often draw from international experience and are influenced by the tactical repertoire of one another, as evidenced by the numerous creative, non-violent resistance actions that are very similar in scope and technique. These actions often involve online and offline activism, nonviolent direct action and cultural resilience tactics by using the language of art and culture to convey a political message.

Previous research on anti-austerity protests has established that doublemovements (i.e. pushes in favour of the welfare-state and against market mechanisms) (Polanyi, 2001) were strongly influenced by the party system, as happened in Latin America, where political parties did not provide channels for dissent from neoliberal policies, and the majority of the parties favoured social cuts. For the political system, it meant an abdication of responsibility by representative institutions in the face of citizen demands, and consequently, a crisis of the welfare state (Della Porta, 2017). In fact, popular resistance to market orthodoxy strengthened the established parties of the left and ultimately contributed to the election of leftist presidents, as was the case in Chile, Brazil and Uruguay (Roberts, 2014). In Europe, the emergence of strongly progrowth planning policies provoked a shift towards entrepreneurial urbanism, comprised of large investments in real estate and uncontrolled debt that led to price bubbles, especially in Ireland and Spain (Norris and Byrne, 2018).

The global financial crisis in 2008/2009 elevated housing issues to the level of national and international debate and protest, offering academics the possibility of a framework for analysis that, on the one hand, studies housing as a commodity, and on the other hand, studies housing as a right (Pattillo, 2013). Within the austerity policies that followed the financial crisis, housing movements operated in a new context when it came to critiquing the economic crisis. The combined appeal of a broad social base which is not limited to the drained mortgage holders (but also the homeless, immigrants and poor students) along with the social movement's capacity to mobilise and expand the legitimacy of housing rights as 
a socio-political outcome, sets the stage for the dispute over who and what affordable housing is for. In Ireland, the increasing homeless figures, the high levels of mortgage arrears as well as the critical housing crisis have, more broadly, been significant in terms of the interpretation of the crisis by activists as well by other social actors (Gaynor, 2018). Their interpretation is relevant for protest framing and its resonance (Della Porta, 2017).

Communities worldwide are responding to rising levels of housing precarity. More recently, scholars have started to approach resistance in nuanced ways, casting a new light on the politics of contemporary urbanity. Resistance against housing precarity is emerging from surprising places, uninhabitable 'homes' and multiple violent histories (Lancione, 2019). The recent resurgence of occupationbased practices across the globe cannot be understood outside a broader narrative of urban development, dispossession and resistance (Brickell et al., 2017). The politics of resistance, in the context of this paper, is understood as a process of resistance and creation, where people mobilise to form non-capitalist, egalitarian and solidaristic forms of political, social, and economic organisation, focusing not only on oppression and vulnerability, but also on radical possibilities to (re)make the city anew (Pickerill and Chatterton 2006, Lancione, 2019; Vasudevan, 2015). The landscape of protest and resistance in the city is where people have converged to build alternative life worlds and articulate new forms of contentious politics (Vasudevan, 2015), raising important questions about how the action-protest (re)made the city, (re)made resistance and ultimately

(re)made politics.

Counter movements to the neoliberal housing model can be found as a result of the pressure of social movements and political contestation. For instance, Ronald and Lee (2012) analyzed the de-commodification of housing in South Korea, Feliciantonio (2016) investigated Spanish social movements in the context of housing and evictions in Spain, and Rolnik (2014) examined the many ways homeless movements demarcate non-capitalist possibilities. Overcoming many challenges, social movements for housing have tried to settle on an agenda of rights and achievements that may be able to reverse some of the neoliberal housing trends. Based on this premise, this study intends to shed light on the possibilities for housing movements to create a space for an expansion of the debate about commodified housing models, taking advantage of the basic contradiction of housing in contemporary capitalism ( Rolnik 2013, Libertun de Duren 2018 ).

These phenomena are explained in this article through examining urban movements, along with other anti-neoliberal movements and changes in political strategies among social movements. To that end, I use a contentious politics 
approach as a framework to examine the most recent dynamics in social movement developments including protests against contemporary public housing policies. Social movement research has focused on elements of urban social movements at national and transnational levels, often focusing on macro-level variables that influence episodes of contention and the diffusion of social movement information and protest (Myers, 1994).

As explained by Tarrow (1998, p. 71), contention escalates when people gain the external resources to escape their compliance and find a way to use those resources. It also increases when they are threatened by costs that are too high, or which outrage their sense of justice. External resources and opportunities are two macro variables which affect collective contentious political action and produce episodes of contentious politics but only if they are "combined with high levels of perceived costs for inaction." While Tarrow's political opportunity theory privileges macro level variables in his explanations, and assuming the housing crisis on its own is not sufficient to explain the protests, I investigate which other factors affect individual incentives to protest, including their capacity to use those resources. It is possible that political opportunities affect the cost of inaction (i.e. existing grievances, in a closed opportunity context, may further increase the cost of remaining inactive) and influence the emergence of protest and the form it takes, but only to the extent that they affect variables at the micro level. The main determinant in the emergence of protest and the form it takes is individual choice (Naughton, 2015).

Building on these elements and considering the growing prominence of contemporary networks of contentious politics, this article argues that the explosion of social protest is a dynamic response to austerity governance which, especially in Ireland's case, it involves rebuilding solidary through reconstructing solidarity through dispersed networks of resistance and resilience (Gaynor, 2018). Responses to urban austerity in the digital age are producing changes in repertoires of contention, allowing activists to engage in new forms of contentious activity and to adapt existing modes of contention to online and offline environments (Garrett, 2007). Communication in real time is cheaper, inclusive and attends to the necessity of creating social protest in online platforms, such as Facebook, Twitter and blogs. These new digital networks promote the emergence and renovation of social protest (Castells, 2007; Garrett, 2007). The participation of the public, online and offline, is aimed at influencing government and public policy (Groshek and Bachman, 2014) and it is proven to be effective in promoting citizen mobilisation (Vromen, 2017; Ribaudo et al., 2016).

The above elements of current urban social movements are important for the study of housing movements in the post-crisis context and can be applied to the 
contemporary state of housing protest in Ireland. Furthermore, I argue that the $\mathrm{HSH}$ has achieved success in some respects, although it has not been able to improve the conditions of homeless people in Dublin at this particular moment in time. However, this draws attention to the impacts produced by their direct action and, in the remaining part of this paper, I consider the increasing growth of direct action as a way to reach positive outcomes through an engaging repertoire of contention.

\section{Study design}

This article is a qualitative study based on interviews with housing activists, who provided empirical evidence on how dissatisfaction is organised when it comes to the current neoliberal housing regime in Ireland. I opted for qualitative methods as they can reveal new information, provide insights on motivations, and uncover the distinctive views of the research participants (Mason, 2017). The aim of this study was to explore the experience of housing activists in creating a public debate about the current housing model. One-to-one, semi-structured interviews were the most appropriate instrument to access this knowledge and to enable an indepth exploration of the issue. Fieldwork was conducted from 2018 to the present and included 34 interviews with Dublin-based activists. This article is based on data collected from 23 interviews with grassroots movements activists, 9 interviews with housing charities activists plus two interviews with public officials engaged in the provision of housing. Activists were recruited using the snowball method, where research participants helped to recruit future participants from among their acquaintances. Many interviewees came from housing movement networks and represented a variety of housing movements around Dublin. Participants were eligible if they had experience in political engagement in social mobilisation in areas related to housing and were willing to give informed consent.

Interviews took place in neutral and accessible places in Dublin and lasted, on average, one hour. An interview script was used to the guide the questions which included questions about the participant's experiences when it comes to mobilisation, perceptions, and strategies to achieve the goals of their organisation. The interviews and supporting data collected helps to explain the changes towards more direct forms of resistance. They provided details about respondents' organizations and their political engagement. These interviews were recorded with consent and transcribed in English. This data was coded and analysed using thematic content analysis (Kvale, 1996) with the support of the NVivo computer software package. During the coding process, I looked for dominant topics in the experiences and strategies of research participants by identifying common themes in the interviews (Saldana, 2009). To increase the validity of the interpretation, I 
used triangulation (between sources and methods). In this way, the rigour of this study was further improved by producing an interpretation of the interviews, which were read many times and analysed for constant comparison, keeping in mind that no interview data is not self-evident (Mason, 2017). This research obtained approval from my university's research committee and all participants gave an informed consent to be interviewed. Anonymity was ensured for all respondents. To protect their anonymity, research participants are referred to, throughout this article, by the type of organisation they belong to (housing organisation, housing charity) or their engagement with the government (public official).

\section{Mobilisation for housing rights in Ireland}

The cost of austerity budgets is disproportionately felt on low income families and it has a devastating effect on this group, where large cuts to regeneration projects, public services and community developments are implemented (Peck, 2012). Unlike the vigorous social protests in other European countries that suffered similar austerity programmes in the early stages of the economic crisis, such as Greece and Spain, Ireland did not follow a similar path of social protest. It had, however, its own path of protest. The media presented Ireland as a stoic and passive nation when compared to Spain and Greece (Allen, 2012) but this view does not correspond with the historical experience of mass protest in Ireland (Naughton, 2015). In contrast to the antieviction movement in Spain and the antiausterity movement in Greece, Ireland's mortgage debt crisis only reached its peak in 2013, five years after the initial crisis, meaning that post-crash, new housing movements did not emerge following the economic crisis. And when it finally emerged, it was the issue of family homelessness rather than the issue of indebtedness and evictions in the private sector that emerged as the focus for the new movements (Hearne et al., 2018; O'Callaghan, 2015; Romanos, 2014).

The post-crash housing movements can be categorised into two distinct groups: the community-led movements participating in the early anti-austerity protests and the movements that emerged in response to the homeless crisis and the housing shortage in the private sector. The first wave of housing movement protest involved "tenants' movements", communities that came together against displacement and social housing plans relating to urban regeneration projects implemented through Integrated Area Plans (IAPs) and PPPs (Public Private Partnerships). Those communities, such as Fatima Mansions and Dolphin House, mobilised against regeneration plans and engaged in public advocacy, joining a national alliance with trade unions SIPTU and Unite, to hold the first national antiausterity protests (Hearne et al., 2018). Thus, the first phase of post-crash housing 
movements originated from preexisting community-based movements challenging the course of urban regeneration during the economic upturn.

The second wave was largely formed by housing activists' responses to the issue of increasing homelessness while also encompassing criticism of government policies on the housing crisis, as the government loosely regulates the sector (Lima, 2019), and subsidises the private rental sector (Murphy and Hearne, 2019). In this context, housing campaigners and activists were seeking to bring to the fore new forms of family homelessness, placing the issue in the centre of political debate. The issue of homelessness became the unifying agenda for different movements, offering an illustration of the conjuncture that produces particular movements, in the absence of a wider movement protesting against the housing and property crash, mortgage arrears and rental crisis (Hearne et al., 2018).

In the case of the HSH movement, the level of frustration and discontent with the housing crisis and broad austerity policies mobilised autonomous actors, linking antiausterity claims to the legitimacy of the right to housing. The ability to air grievances and satisfaction towards government responses to the crisis was directed at primarily national political and economic institutions (i.e. banks and government agencies especially NAMA). Housing movements, such as HSH, mobilized supporters through an inclusive collective identity constructed to rebuff the key practices of austerity governance: the collectivization of blame and shame and the disciplining of civil society (Gaynor, 2018).

According to Cannon and Murphy (2015, p.15), the explanation for the absence of large-scale popular revolt against Irish austerity is that Irish society internalises neoliberal values, as part of a 'long-term market society project'. The relatively low motivation and weak social capacity, combined with active state-market forces and collusion with these by key civil society actors, limits the likelihood of protest. However, it does not mean groups have not reacted at all. It means that protests in Ireland are peculiar if compared to the Spanish Podemos and the Greek Syriza. Furthermore, building occupation is not a traditional form of urban protest in Ireland - but this is changing.

It would be incorrect to suggest that Irish society was quiescent and offered no resistance to the implementation of austerity measures, especially in light of the frequent rallies drawing attention to problems in the country's housing sector. O'Connor (2018, p. 66) attributes this misconception about the lack of antiausterity protest to a number of reasons. First, successive Irish governments projected an image of a stoic population sharing the responsibility for financial recklessness during the Celtic Tiger period. A second reason is the low level of coverage of peaceful and small protests, apparently not worth an international audience. A considerable number of localised, single-issue protests took place 
between 2010 and 2013 (Naughton, 2015). This mobilisation happened mostly in the early stages of the crisis and was overshadowed by the massive subsequent protests in other countries hit by austerity. And thirdly, the Right2Water campaign started when mass protests had largely been channelled into anti-austerity political parties with seats in the parliament, as in the case of SYRIZA and Podemos. Rather than being an opportunity for mobilisation that matters (an increasing grievance with adjustment packages); the public was incentivised to be resilient and patient when it came to the difficult "phase" the market was going through, a strong strategy that sought to assure that the general public would cope with the crisis and pull "the teeth from mobilizing forces" (Silva, 2009, p. 32).

More recently, housing activists have engaged in direct action that involves the occupation of vacant buildings, as a strategy for increasing visibility, avoiding evictions and offering services to the homeless. One of the most emblematic cases was the occupation of the Bolt Hostel in 2015 and the high-profile Apollo House in late 2016 (which is the case I am examining). Both occupations made political claims that challenged private property norms, i.e. the right to use property on the basis of need rather than for financial gain, as building occupants highlighted the "absurdity" of wasting valuable urban spaces by keeping them unused. Their campaign expounded the failures of the entrepreneurial urban model (O'Callaghan et al., 2018).

The challenge for researchers working with the political opportunity framework is to identify which aspects of the external world affects the development of which social movements and how (Meyer, 2004). However, Ireland's peculiar political opportunity structure, which operates in the specific context of the housing crisis in Ireland, has created specific types of activism. In the next section, I examine the emergence, spread and functioning of the HSH movement in December 2016 and January 2017.

5. Origin and development of the apollo house occupation by home sweet home

A new set of grassroots groups have been responding with direct action to the housing crisis, some of them developed into housing activism after water protests (Gaynor, 2018). One of those groups is the Irish Housing Network (IHN), which is made up of a broad coalition of grassroots housing organisations. ${ }^{2}$ The $\mathrm{IHN}$, together with trade unions, artists and volunteers, staged a large and high-profile occupation of a vacant building, Apollo House, as part of the Home Sweet Home (HSH) direct action. Created in 2015, the IHN have been influenced by activist models developed by the PAH in Spain (Di Feliciantonio, 2017). IHN operates as a horizontal, coalition-style network, where the majority of the associated groups 
operate at the neighbourhood level, supporting local actions. The more visible and direct actions are supported by IHN as a group.

On 15 December 2016, a group of about 100 people occupied Apollo House, a NAMA-controlled empty office building in Dublin's city centre and offered it as emergency accommodation for homeless people. The building had been used in the past by the Department of Social Protection and had been vacant since 2015 . Around 30 rough sleepers were accommodated on the first night the HSH group opened Apollo House's doors. In the space of six-weeks this number rose to 76 people. The group that occupied the Apollo House included

"( ... ) experienced trade unions activists - people who have years of industrial relations expertise, there were a bunch of actors who had household name recognition ( ... ) and then you had there grassroots groups, volunteers from a variety of backgrounds and they maybe would be a little bit more experienced" (Grassroots Activist 6).

The Apollo House occupation focused the debate on homelessness and NAMA properties, bringing the issue of homelessness to a political platform ( $\mathrm{O}^{\prime} \mathrm{Callaghan}$, 2018). This reflects the second wave of housing activism, marked by loose networks of organisations united around the agenda of housing rights and bringing the homelessness crisis into public view. The Apollo building occupation led to people talking about homelessness during the economy recovery, rather than during the height of the economic crisis, as happened in Spain (Barbero, 2015). The public response associated with the timing of the building occupation is best voiced by the quote of one respondent:

"The idea started because people were dying on the streets. ${ }^{3}$ It was 2017 and it was a really cold winter. It was absolutely crazy from the inside. How to do this, how to organize jobs. But it was a national cooperation. I don't know if it was because it was Christmas time, if it was the artists, or if it was the workers in care [doctors, cooks, cleaners, nurses]. It was an incredible human effort to not let people die on the streets" (Grassroots Activist 10).

The HSH demanded the right to housing and focused on NAMA in order to criticise the government response to the crisis. Along these lines, the HSH mobilised the frustration and discontent of supporters around two main targets: 1) criticizing the use of vacant government buildings owned by NAMA and, 2) obtaining improvements in homeless services. These targets were approached from the perspective of raising the issue of homelessness in the city by confronting the current government housing and homelessness policy. The first target was achieved in the form of the occupation of a government-owned building, while the group demanded that NAMA make properties available to house the homeless (O'Callaghan, 2018). There is a symbolism to a NAMA building, in terms 
of how it represents the housing crisis and the property problem in Ireland (Byrne, 2016). The occupation of a NAMA building called attention to the number of unoccupied NAMA buildings and other sites currently vacant. The second target was reached with the provision of a dry hostel with good quality accommodation for homeless people in Dublin. The group was able to provide accommodation, medical services and food, with the intention of highlighting the poor standards and unsafe conditions in homeless accommodation in the city, as put by an $\mathrm{HSH}$ organiser:

"We were showing how good was the service provision, potentially, opposite to that most poor standards. Volunteers with no pay over a month to Christmas could run a place to higher standard against a massively funded them a semi-private NGO"

(Grassroots Activist 1).

In summary, the main demands of the groups included: 1 . the government declaring a national housing emergency; 2 . the implementation of rent controls; 3. a reduction in the number of evictions; and 4. guaranteed emergency beds for homeless people for a period of six months, instead of the common "one night only" bed policy.

The campaign attracted the attention of the media and the public, generating an important debate on housing shortage, evictions and the increasing number of homeless people in the city. The occupation received solid support from the public and the strong endorsement of local musicians and celebrities, such as actor Saoirse Ronan, film director Jim Sheridan and musicians Hozier, Christy Moore, Glen Hansard, Damien Dempsey and Liam O Maonla ı. Their support was exceptionally important in drawing public attention to the HSH campaign. Both activists and celebrities willingly engaged with the media, taking part in collective interviews, TV appearances and offering free gigs on the street outside Apollo House that attracted thousands of people. As one of our respondents noted, the celebrities involved in the occupation had a key role in gaining the support of the public, especially after an interview on the Irish television programme, The Late Late Show:

"So, it was the most watched program in Irish households. There is this guy that everybody likes his music, he is a nice man, he is a good fella. He is saying: this is wrong [homelessness]. He is not making a political speech, he is just speaking to my mom, my grandma, my next-door neighbour, saying this is wrong, we have to start doing something" (Grassroots Activist 6).

Moreover, the occupation itself was highly publicised on social media. The group's actions mobilised some of the public anger towards the worsening of the housing crisis and the slow government response to it. Hundreds of people volunteered to help the movement, offering their skills as cleaners, hairdressers 
and medical experts, while donations of food, medication, beverages and mattresses flooded the building. Volunteers, supporters and donors were engaged, largely on social media, which was used to spread the message and share developments. This respondent commented on the public's outpouring of support for the occupation:

"The level of volunteering, and messages that kept coming, tweets went up, people sending emails, roster being done every day, bringing people around to different jobs. The level of people who wanted to come in and help was impressive, I had never seen something like this" (Grassroots Activist 8).

Across social media, especially on Facebook and Twitter, people praised the initiative. The hashtags \#ApolloHouse and \#HomeSweetHome were widely shared on Twitter and were trending topics for several days. Other hashtags, such as \#OcuppyNama and \#EndHomelesssNow were also popular at the time. These two hashtags in particular called for the occupation of other buildings controlled by NAMA and demanded government action to tackle the issue of homelessness more effectively. Facebook and Twitter were widely used to keep supporters informed on the latest developments in the campaign and volunteers managing social media were careful in showing how the dilapidated office building had changed into good standard accommodation. The HSH GoFundMe website (crowdfunding initiative) received donations exceeding e160,000 by the end of the Christmas period.

Despite the strong support from the public, the movement had its critics, who condemned the occupation in the press. The chief executive of the Dublin City Council, Owen Keegan, for example, criticised the group's activities describing them as an "inappropriate response to keeping rough sleepers off the streets in the capital", while insisting that enough beds existed in professionally managed hostels. ${ }^{4}$ Other critics pointed out the building health and safety concerns, which would make it unsuitable for use as a shelter, although it was cleared as safe at the start of the occupation by Dublin Fire Brigade.

Two days after the occupation started, the receivers appointed by NAMA launched a High Court action aimed at regaining possession of the property. A backlash of criticism from the public followed, especially after Dublin City Council's statement that sufficient and available accommodation existed, which was not confirmed by charities working with homeless people. ${ }^{5}$ The government insisted that sufficient facilities for the homeless existed, but homelessness charities and occupation organisers argued that the services provided were inefficient, inadequate and low quality. On 21 December 2016, following a legal action in which the building receivers sought to end the occupation, alleging illegal trespassing, a High Court judge ruled that the Apollo House occupants had to 
leave the building on 11 January by noon. Justifying his ruling, the judged declared that the occupants were trespassers and had to vacate the building. The judge, however, acknowledged in his ruling the lack of beds for the homeless in Dublin and, although the group were not allowed to stay there indefinitely, they could remain in the building over Christmas and the New Year. To HSH organisers, the High Court ruling was, in some way, a morale boost, as one of the respondent notes:

"But essentially, he said you are not allowed to stay there indefinitely, but I will give you long enough to prove your point. That's not what he says, that you will have long enough to sort your affairs, but clearly that judge is saying, you know what, there is definitely something wrong here. These artists, these actors, these trade unionists, they shouldn't be occupying this building which is owned by the state, these people shouldn't be sleeping on the streets" (GA7).

Following the High Court order, the Minister for Housing sought to strike a deal with the occupiers. This deal included 42 extras beds in two weeks in the city hostel accommodation system, e4 million to be invested in two new facilities in Dublin City Centre and a further commitment to funding of e5.35 billion to prioritise homelessness and to accelerate the overall supply of housing. Regarding the latter, the minister was referring to the Rebuilding Ireland action plan: a governmentbacked scheme to deliver new homes nationwide. Since its inception, the Rebuilding Ireland strategy had been met with criticism. This plan is based on a careless assumption that boosting new private sector home supply would make houses more affordable. Many experts say that at current pace, the housing crisis will not be solved by 2021, as the government has assured. The strategy does not include measures to prevent more families becoming homeless or stop the trend of mortgage arrears and repossessions. Despite the inconsistencies in the Rebuilding Ireland strategy, activists and the government reached an agreement where organisers stopped accepting new occupants (a requirement in the High Court order) and they slowly reduced their services until the day they had to leave the building. On 12 January, the occupiers decided to leave Apollo House. All the remaining occupiers left the building voluntarily to be moved either to a house or temporary accommodation paid for by the campaign.

A significant outcome of these developments for the interviewed, was that their movement was able to prove a point: there are solutions to the homeless crisis. One respondent describes the impacts of the building occupations following her involvement in $\mathrm{HSH}$,

It was a collective action. And if we could learn something about it, apart from the divisions, apart from anything else, is how strong we are when we collectively work together (Grassroots Activist 6). 
In terms of the success or failure of the occupation, some felt that it was both at the same time, as noted by one of the respondents,

In terms of actual direct action, we were successful in taking the building and holding to it, but our perspective of this was to spread to some extent in a movement

(Grassroots Activist 1).

According to the interview participants, HSH activists parted ways after the occupation in order to engage in other housing-related activities at the grassroots level of mobilisation. Despite the potential possibility of creating new political subjectivities,

HSH did not spread to become a larger movement. As noted by Hearne et al., (2018), the movement's restricted focus on homelessness was unsuccessful in connecting with the broader impacts of the housing crisis. The emphasis on the most vulnerable groups in society (the homeless and drug addicts) prevented other groups affected by the housing crisis (those who are indebted, evicted, or temporarily living at friends/family) from relating to the occupation. After the end of the building occupation, the movement was not kept under the flag of $\mathrm{HSH}$.

\section{Discussion - public responses to neoliberal housing policies}

The occupation of Apollo House marked a meaningful departure from earlier patterns of housing protest, which were, for the most part, localised and sporadic. In protesting against the conditions of homeless accommodation and the deficient use of vacant building and sites, the HSH group was also challenging the current housing model that places the provision of accommodation by the private sector at the forefront of government policy and it was also articulating new forms of contentious politics. As discussed previously in this paper, the grievances expressed by the Apollo House occupation were directed at the state's slack response to increasing homelessness, the implementation of neoliberal housing policies and the imbalanced use of urban space.

As it happened, the repertoires of protest were used as instruments to put pressure on decision-makers. This action-protest helped the movement to seize opportunities and strategize in order to create a repertoire to (re)create resistance and ultimately remake housing policy. However, protests should not be seen purely in instrumental terms (Taylor and van Dyke, 2007). The HSH housing protest promoted, in fact, a sense of collective identity around a problem that affects more and more people living in Dublin each day. The political context influences whether disruptive tactics have successful results in local campaigns to improve the conditions of homeless people (Cress and Snow, 2000). When analysing the factors that influence a social movement's selection of tactics, macro historical factors as well as internal movement processes influence tactical repertoires and 
innovations, as suggested by theorists of contentious politics (Taylor and van Dyke, 2007). Negative developments in housing policy and the rise in the number of homeless raised the prospect for political mobilisation. HSH was driven by the knowledge that extreme unaffordability can lead to eviction and homelessness, as participants recognised that the official channels for housing delivery were failing to provide affordable accommodation.

The visible effects of decades of neoliberal housing policies in Ireland - and in many other countries - exemplify the tension between housing as a financial asset, used as a commodity exchange for investors, as well as health, income and education. The increasing levels of homelessness in the context of the financialisation of housing illustrates a resolute government commitment to the prerogative of profits for the private housing market, whereas housing movements claim the vacant buildings through direct action, associated with articulating an alternative project for using urban space. By emphasising property vacancy as an opportunity to highlight the contradictions of the property market (O'Callaghan et al., 2018), housing activists are reclaiming urban space and resisting neoliberal housing policies.

Neoliberalism is arguably the main cause of protest movements and occupations worldwide, a consistent trend observed since 2010 (Della Porta, 2015). Activists in the HSH movement criticised the fundamental incompatibility between neoliberalism development models - where financial actors keep vacant spaces open for development speculation ${ }^{6}$ - while pushing the conception of housing as a basic right. The occupation of a building technically owned by "the people" - because NAMA is a government agency that acquired property development loans from Irish banks - was indeed a meaningful statement. The claiming of a vacant space in one of the most attractive locations for foreign direct investment in Dublin city centre had, as its main objective, highlighting that the housing crisis was more of a political decision and not only due to the lack of space for housing. As observed by Della Porta (2015, p.4-5), recent movements against austerity measures in Europe are an expression of grievances harboured against neoliberalism. She argues that they are reactions to the "crisis of/in a late neoliberal system ( ... ) which takes the form of a crisis of responsibility". In this way, the building occupation organised by HSH consisted of an alternative social project that emerged as a response to the neoliberal crisis, in an increasingly financialised property market shaped by government decisions that prioritise housing development in the private sector.

Another important challenge for HSH was the engagement of the homeless in the political protest. Homeless participation in organised protests about homelessness is unusual, as the homeless are often considered a "hard to 
represent" group, because of the episodic, transitory and often chaotic character of homelessness. They have high levels of spatial mobility and are diffusely distributed within cities, and they often move in and out from one homeless service-delivery area or subsistence node to another (Corrigall-Brown et al., 2009; Mayock et al., 2011, 2015; Wagner and Cohen, 1991). The HSH focus on the homeless issue put this very vulnerable group at the centre of the debate. Considering the stigma attached to the status of being homeless and their circumstances, HSH organisers had no other option but to speak on their behalf. This might have prevented the movement from achieving an overarching narrative to the crisis that not only focused on homelessness, but also on those affected by the housing crisis.

Within this alternative project, HSH performance repertoires mixed politics with entertainment, which had a range of effects, including a transformation in beliefs (Taylor and van Dyke, 2007). Through the building occupation and related protest events to keep the occupation going, HSH participants experimented with new repertoires of contention, while sending signals about the possibility of collective action as a response to the housing crisis. This collective action created feelings of solidarity evidenced by the number of volunteers, donations and support from the members of the public.

Studies by Cress and Snow (2000) on the success of local campaigns to improve the conditions of homeless people found that disruptive repertoires of contention, such as tactics like blockades and building occupations, are more effective in cities where movements have sympathetic political allies (Taylor and van Dyke, 2007). In cultivating some key alliances, HSH gathered a strong network of allies that included celebrities, NGOs, members of parliament, trade unions, and concerned citizens. Celebrities spoke to the media and offered free gigs, NGOs involved in the homeless cause supported the movement (in a moderate way and not all of them) with legal assistance and personnel; some members of the lower house of the Irish parliament (TDs) wore the movement's t-shirt in the parliament and defended the group's agenda. Thus, the movement came to control the narrative of the occupation, gaining the support of the public as the time passed. In that sense, a combination of active allies from trade unions (organisational experience), the support of the media (celebrities, musicians, news coverage), parliament members, NGOs and the general public enabled the movement to justify the occupation, to gain support and to continue to operate for nearly one month. The cultivation of allies was necessary, in combination with disruptive tactics, which led to the realisation of a potential capacity to influence the government agenda. The strategies and tactics of the HSH movement were focused on influencing institutional politics and policy, while at the same time offering a service to the 
homeless. In the context of the housing crisis in Dublin, the public remains outcome-focused, as they are attentive to the outcome of housing policies intended to respond to the housing issue.

Considering the above aspects, it is possible to determine that the lack of effective responses to the housing crisis was the trigger that initiated a potential movement for housing rights. The narrative adopted by the group highlighted a dimension that was underplayed and not previously in the public debate: the organisational capacity of citizens to press government and explore alternative policies to respond to the crisis. By making the problem visible in this way, $\mathrm{HSH}$ opened up the possibility for urban political movements to flourish and to question the neoliberalization of housing policy in Ireland.

As for the apparently abrupt end of the movement, it was a phase of decline, but it does not necessarily mean failure (Miller, 1999). Successful movements are usually those with very specific purposes that might dissipate when they reach their goals. Some movements have broader agendas and goals, thus less chance of outright success (Christiansen, 2014). Despite the high expectations, the occupation of Apollo House came to an end in January 2017. Since then, following the relative success of the occupation, the activists involved in it continued to develop their housing activism agenda. According to the interviews, many of those involved joined other housing movements, such as the Raise The Roof campaign, which encompasses a large variation of more established groups and other grassroots organisations, and the Take Back The City movement which has occupied a number of properties in Dublin's north inner city. Both groups have been holding rallies and protests to highlight the housing crisis.

\section{Conclusion}

The central purpose of this paper was to explore the empirical and theoretical basis for the strategies used by housing movements to effect policy change, as well as the practical implications of their highlighting the increasing number of homeless in Ireland. This investigation draws on the case study of the occupation of Apollo House by the HSH group, exploring the campaign for better use of urban space in the city. The analysis presented here shows that, given the broader circumstances of housing policies implemented in recent years, with a rising dependence on the private sector to sort out the housing crisis, rising rents and growing homelessness, the housing problem has led to the creation of an activist movement. While the government proposes a market solution to a market failure that defies logic, HSH was able to legitimate its protest methods by blending direct actions with the use of innovative tactics that resonated well with the public. 
This research has shown some of the aspects of mobilisation that have been underplayed and missed in the literature. The challenge of opening up a new discursive political space regarding housing policy in Ireland was taken up by a combination of strategies that involved direction action, the mobilisation of key allies and a strong narrative about the homeless crisis. The occupation of Apollo House is part of a significant protest cycle that is finding an echo in many parts of the country. HSH was not able to make changes within the existing policy system, changes that would reflect the group's desired outcome for housing policies. But they did generate an alternative proposal of homeless intervention, one the government refuted - and still refuses to implement. It is important to consider that in the context of the post-crisis situation that Ireland finds itself in, strong state-market relations limit the prospect of these movements being able to influence housing policies.

Even if $\mathrm{HSH}$ does not exist now in its original form, they have succeeded in revealing a side of political Ireland that defied the depiction of the country as a stoic country, obediently accepting austerity urban governance models. While many assumed political resistance was weak in the country, especially in the media, critical and politicised members of the public showed willingness to get involved in a movement aiming to change government housing policy - both through direct action and institutional politics, since many politicians of the left with seats in parliament, as well as trade unions, have been involved in recent housing protests.

The analytical framework outlined in this paper presents the key dimensions of social protest around the housing issue in Ireland, articulating an analysis on antineoliberal resistance, social movements, and housing policy. This framework provides insights into urban activism for affordable housing in Dublin, but it was limited in that further understanding about the relationship between neoliberal urbanism and various forms of urban collective action is still required. While my analysis emphatically underlines the centrality of urban austerity policies in prompting activism in housing resistance movements in the wake of the housing crisis, other questions about the nature of 21 st century urban mobilisations remain open, in particular, the spaces of resistance that are created. Further research can explore how Irish housing activism compares with respect to other housing movement crises elsewhere in Europe.

Notes

1. "Direct Provision" is an accommodation service offered by the Irish government to asylum seekers in Ireland while their claims for refugee status are being processed. This system has faced severe criticism from human rights activists, as many asylum 
seekers in the State's direct provision system spend years waiting for the results of their refugee status application in conditions that may be damaging to their health and welfare. In late 2017, there were 5,096 persons registered as living in Direct Provision in Ireland (Irish Refugee Council, 2018).

2. At the time of writing, other housing coalitions - such as the National Homeless and Housing Coalition and the Irish Coalition to End Youth Homelessness - also exist. However, since the Home Sweet Home occupation was organized and supported by the Irish Housing Network, I have focused my analysis on them.

3. "Seven people died sleeping rough in less than three months, campaigners say", Irish Independent, 29 $9^{\text {th }}$ November 2017: https://www.independent.ie/breaking-news/irishnews/ seven-people-died-sleeping-rough-in-less-than-three-months-campaignerssay-36364092.html

4. "Apollo House accommodation 'substandard', council chief says" The Irish Times, $28^{\text {th }}$ December 2016: https://www.irishtimes.com/news/ireland/irish-news/apollohouseaccommodation-substandard-council-chief-says-1.2919209

5. See full statement here: http://www.intallaght.ie/dcc-response-to-apollo-housedecision/

6. 114 sites and properties were lying empty in the capital and county amid a housing crisis up to September 2018: https://www.irishtimes.com/news/environment/cityvacant-dublin-shundreds-of-multimillion-euro-empty-sites-and-properties-

1.3635595

\section{Acknowledgements}

This paper draws on research with housing activists based in Dublin. I would like to thank them for their willingness to take part in this study. Their contribution to this research was invaluable. I also want say thank you to Dr Mary Murphy, Dr Niamh Gaynor and Professor David Farrell for their comments in early versions of this article. Many thanks also to the three anonymous referees for their insightful comments and suggestions.

\section{Funding}

This article was funded by Irish Research Council.

Notes on contributor

Dr Valesca Lima is a postdoctoral research fellow at Maynooth University specialising in social movements, housing policies, and governance.

\section{References}

Aalbers, M. B. \& Haila, A. (2018) A conversation about land rent, financialisation and housing, Urban Studies, 55, pp. 1821-1835.

Allen, K. (2012) Recession and the new resistance, Irish Marxist Review, 1, pp. 3-12. 
Barbero, I. (2015) When rights need to be (re)claimed: austerity measures, neoliberal housing policies and anti-eviction activism in spain, Critical Social Policy, 35, pp. 270280.

Brickell, K., Arrigoitia, M. F. \& Vasudevan, A. (2017) Geographies of Forced Eviction: Dispossession, Violence, Resistance (Berlin: Springer).

Byrne, M. (2016) Asset price urbanism' and financialization after the crisis: Ireland's national asset management agency, International Journal of Urban and Regional Research, 40, pp. 31-45.

Cannon, B. \& Murphy, M. P. (2015) Where are the pots and pans? Collective responses in Ireland to neoliberalization in a time of crisis: learning from Latin America, Irish Political Studies, 30, pp. 1-19.

Castells, M. (2007) Communication, power and counter-power in the network society, International Journal of Communication, 1, pp. 238-266.

Christiansen, J. (2011) Framing theory, in: Sociology Reference Guide: Theories of Social Movements, pp. 145-169 (Pasadena, CA: Salem Press).

Corrigall-Brown, C., Snow, D. A., Smith, K. \& Quist, T. (2009) Explaining the puzzle of homeless mobilization: an examination of differential participation, Sociological Perspectives, 52, pp. 309-335.

Cox, L. \& Nilsen, A. G. (2014) We Make Our Own History: Marxism and Social Movements in the Twilight of Neoliberalism (London: Pluto Press).

Cress, D. M. \& Snow, D. A. (2000) The outcomes of homeless mobilization: the influence of organization, disruption, political mediation, and framing, American Journal of Sociology, 105, pp. 1063-1104.

DAFT Report. (2018) The Daft Rental Price Report (Dublin, Ireland).

Della Porta, D. (2015) Social Movements in Times of Austerity: Bringing Capitalism Back Into Protest Analysis, 1 ed. (Cambridge: Polity).

Della Porta, D. (2017) Late Neoliberalism and its Discontents in the Economic Crisis Comparing Social Movements in the European Periphery j Donatella Della Porta (UK: Palgrave MacMillan).

Department of Housing, Planning \& Local Government (DHPLG). (2019). Homelessness Report - June 2018. Department of Housing, Planning \& Local Government, Dublin, Ireland.

Feliciantonio, C. D. (2017) Social Movements and Alternative Housing Models: Practicing the "Politics of Possibilities" in Spain, Housing, Theory and Society, 34, pp. 38-56.

Fominaya, C. F. (2015) Debunking Spontaneity: Spain's 15-M/Indignados as Autonomous Movement, Social Movement Studies, 14, pp. 142-163.

Garrett, R. K. (2007). Protest in an Information Society: a review of literature on social movements and new ICTs. Information, Communication \& Society, 9, pp. 202-224.

Gaynor, N. (2018) Governing austerity in Dublin: rationalization, resilience, and resistance, Journal of Urban Affairs, 0, pp. 1-16.

Groshek, J. \& Bachman, I. (2014) A Latin spring? examining digital diffusion and youth bulges in forecasting political change in Latin America, in: Digital Technologies for Democratic Governance in Latin America (UK: Routledge).

Hearne, R., O'Callaghan, C., Kitchin, R., Feliciantonio, C. D. (Eds) (2018) The Relational Articulation of Housing Crisis and Activism in Post-Crash Dublin, Ireland, in: Rent and Its 
Discontents: A Century of Housing Struggle (New York: Rowman \& Littlefield International).

Housing Agency. (2018) Annual Summary of Social Housing Assessments (Housing Agency, Ireland).

Ireland, S. J. (2019) National Social Monitor - Spring (European Edition) (Dublin: Social Justice Ireland, Sandyford).

Irish Refugee Council. (2018), Statistics - Republic of Ireland j Asylum Information Database

(Statistics) (Ireland: Irish Refugee Council).

Kvale, S. (1996) InterViews: An Introduction to Qualitative Research Interviewing, 1 ed. (Thousand Oaks, CA: SAGE Publications, Inc.).

Lancione, M. (2019) Radical housing: on the politics of dwelling as difference, International Journal of Housing Policy, pp. 1-17. doi: 10.1080/19491247.2019.1611121

Libertun de Duren, N.R. (2018) Why There? Developers' Rationale for Building Social Housing in the Urban Periphery in Latin America, Cities, 72, pp. 411-420.

Lima, V. (2019) Towards an understanding of the regional impact of Airbnb in Ireland, Regional Studies, Regional Science, 6(1), pp. 78-91.

Mallon, B. (2017) A radical common sense: on the use of direct action in Dublin since 2014, Interface: A Journal for and about Social Movements, 9, pp. 46-71.

Mason, J. (2017) Qualitative Researching, 3rd ed. (London, UK: SAGE).

Mayer, M. (2013) First world urban activism, City, 17, pp. 5-19.

Mayock, P., O'Sullivan, E. \& Corr, M.L. (2011) Young people exiting homelessness: an exploration of process, meaning and definition, Housing Studies, 26, pp. 803-826.

Mayock, P., Sheridan, S., Parker, S. (2015) It's just like we're going around in circles and going back to the same thing ... ': the dynamics of women's unresolved homelessness, Housing Studies, 30, pp. 877-900.

Miller, F. D. (1999) The end of SDS and the emergence of weatherman: Demise through success, in: Waves of Protest: Social Movements Since the Sixties, pp. 303-324 (Lanham: Rowman \& Littlefield Publishers).

Murphy, M. P. \& Hearne, R. (2019) Implementing marketisation: comparing Irish activation and social housing, Irish Political Studies, 34, 444-463.

Myers, D. J. (1994) Communication technology and social movements: contributions of computer networks to activism, Social Science Computer Review, 12, pp. 250-260.

Naughton, M. (2015) Protest in Ireland since the bailout, Interface: a Journal for and about Social Movements, 7, pp. 289-308.

Norris, M. \& Byrne, M. (2017) A tale of two busts (and a boom): Irish social housing before and after the global financial crisis. Critical Housing Analysis, 4, pp. 19-28.

Norris, M. \& Byrne, M. (2018) Housing market (in)stability and social rented housing: comparing Austria and Ireland during the global financial crisis, Journal of Housing and the Built Environment, 33, pp. 227-245.

O'Callaghan, C. (2018) Planetary urbanization in ruins: provisional theory and Ireland's crisis, Environment and Planning D: Society and Space, 36, pp. 420-438. 
O'Callaghan, C., Feliciantonio, C. D. \& Byrne, M. (2018) Governing urban vacancy in postcrash Dublin: contested property and alternative social projects, Urban Geography, 39, pp. 868-891.

O'Callaghan, C., Kelly, S., Boyle, M. \& Kitchin, R. (2015) Topologies and topographies of Ireland's neoliberal crisis, Space and Polity, 19, pp. 31-46.

O'Connor, F. (2017) The presence and absence of protest in austerity Ireland, in: Late Neoliberalism and Its Discontents in the Economic Crisis: Comparing Social Movements in the European Periphery, pp. 65-98(US: Palgrave MacMillan).

Pattillo, M. (2013) Housing: commodity versus right, Annual Review of Sociology, 39, pp. 509-531.

Peck, J. (2012) Austerity urbanism, City, 16, pp. 626-655.

Peter McVerry Trust. (2018) Facts and Figures (Facts and Figues) (Ireland: Peter McVerry Trust).

Pickerill, J. \& Chatterton, P. (2006) Notes towards autonomous geographies: creation, resistance and self-management as survival tactics, Progress in Human Geography, 30, pp. $730-746$.

Polanyi, K. (2001) The Great Transformation: The Political and Economic Origins of Our Time (Boston, MA: Beacon Press).

Power, M. J., Haynes, A. \& Devereux, E. (2016) Reasonable people vs. The Sinister Fringe, Critical Discourse Studies, 13, pp. 261-277.

Residential Tenants Board (RTB). (2018), RTB Q3 2018 Rent Index j RTB (Rent Index) (Irel:

Residential Tenants Board).

Ribaudo, M., Torrigiani, C., Cindio, F. \& Palumbo, M. (2016) The university in the Polis: an emerging role of democratic intermediary in e-participation? in: Empowering Organizations, pp. 63-76 (UK: Springer).

Roberts, K. M. (2014) Populism, Social Movements, and Popular Subjectivity, in: Oxford Handbook on Social Movements, pp. 681-695 (UK: Oxford University Press).

Rolnik, R. (2013) Late neoliberalism: the financialization of homeownership and housing rights, International Journal of Urban and Regional Research, 37, pp. 1058-1066.

Romanos, E. (2014) Evictions, petitions and escraches: contentious housing in austerity Spain, Social Movement Studies, 13, pp. 296-302.

Ronald, R. \& Lee, H. (2012) Housing policy socialization and de-commodification in South Korea, Journal of Housing and the Built Environment, 27, pp. 111-131.

Saldana, J. (2009) The Coding Manual for Qualitative Researchers, 1st ed. (Los Angeles, Ca: Sage Publications Ltd.).

Silva, E. (2009) Challenging Neoliberalism in Latin America (Cambridge: Cambridge University

Press).

Tarrow, S. (1998) Power in Movement: Social Movements and Contentious Politics (Cambridge: Cambridge University Press).

Taylor, V. \& Van Dyke, N. (2007) "Get up, stand up": tactical repertoires of social movements, in: The Blackwell Companion to Social Movements, pp. 262-293 (Hoboken: John Wiley \& Sons, Ltd). 
Vasudevan, A. (2015) The autonomous city: Towards a critical geography of occupation, Progress in Human Geography, 39, pp. 316-337.

Vromen, A. (2017) Digital Citizenship and Political Engagement - The Challenge from Online Campaigning and Advocacy Organisations (UK: Palgrave MacMillan)

Wagner, D. \& Cohen, M. B. (1991) The power of the people: homeless protesters in the aftermath of social movement participation, Social Problems, 38, pp. 543-561.

Waldron, R. \& Redmond, D. (2014) The extent of the mortgage crisis in ireland and policy responses, Housing Studies, 29, pp. 149-165. 10.1080/02673037.2013.825694

Watt, P. \& Minton, A. (2016) London's housing crisis and its activisms: Introduction, City, 20, pp. 204-221.

Yates, L. (2015) Rethinking prefiguration: alternatives, micropolitics and goals in social movements, Social Movement Studies, 14, pp. 1-21. 